\title{
PROBLEMA PENEGAKAN HUKUM PELAYANAN PUBLIK OLEH LEMBAGA OMBUDSMAN REPUBLIK INDONESIA BERBASIS PARTISIPASI MASYARAKAT
}

\author{
Edi As'adi \\ Staf Pengajar Program Pascasarjana Universitas Bandar Lampung dan Program \\ Pascasarjana Universitas Muria Kudus \\ Korespondensi: 454dilaw@gmail.com
}

\begin{abstract}
Abstrak
Penyelenggaraan pelayanan publik saat ini menjadi titik sentral tolok ukur tertib hukum administrasi dalam rangka mewujudkan tujuan negara untuk memajukan kesejahteraan rakyat. Ombusdman sebagai lembaga yang memiliki kewenangan pengawasan terhadap penyelenggaraan pelayanan publik diharapkan dapat mewujudkan pemerintahan yang bersih dan baik. Namun demikian, keberadaan Ombudsman tidak sepenuhnya mampu mengatasi praktik tindak pidana korupsi yang berawal dari perilaku maladministrasi oleh oknum penyelenggara pemerintahan. Bedasarkan itu maka di masa depan perlu pembaharuan hukum secara terintegral dan komprehensif yang meliputi substansi hukum yaitu pembaharuan UU No. 37 Tahun 2008 dan sekaligus membangun struktur kelembagaan hukum Ombusdman dan kultur hukum masyarakat dalam mendapatkan jasa pelayanan publik.
\end{abstract}

Kata-kata Kunci: Ombudsman; Pelayanan Publik; Penegakan Hukum.

\begin{abstract}
The focal point of orderliness in administration law is public service performance in order to establish the pupose of the nation which is public's welfare. Ombudsman as institution that has monitoring authority of public service execution is expected to create clean dan good government. Nevertheles, existency of Ombudsman is not fully capable to overcome corruption practice that begins from maladmistration practice. Therefore, comprehensive and integral law reform is needed, including amandement Act No. 37/2008, build Ombudsman as institution, and raise public culture regarding receiving public service.
\end{abstract}

Key Words: Ombudsman; Public Service; Law Enforcement. 


\section{PENDAHULUAN}

Sejarah panjang menjelaskan bahwa sifat dasar manusia sebagai makhluk ekonomi (homo economicus) dikonseptualisasikan dalam terma individu yang mementingkan diri sendiri (self-interest). Keputusan ekonomi manusia didasarkan pada pilihannya yang bersumber dari semua informasi yang diperlukan dan tersedia. Persaingan manusia di era industrialisasi dan kemajuan teknologi (globalisasi ekonomi) cenderung semakin menggerus rasionalitasnya dan lebih mengutamakan kepentingan individualistis masing-masing orang yang secara terus menerus dibangun menjadi sebuah kekuatan personal (personality strength/PS) untuk menguasai atau memonopoli sumber daya yang terbatas. ${ }^{1}$

Sejarah juga menunjukkan proses rasionalisasi dan kekecewaan terhadap kinerja pelayanan publik oleh para oknum birokrat di era globalisasi ekonomi yang semestinya diiringi perubahan paradigma dari pelayanan ala birokratis ke arah pelayanan yang memuaskan pelanggan (konsumen) sebagaimana pernah disinggung oleh David Osborn dan Peter Plastrik. Kedua penulis berpendapat mengenai pelayanan publik berbasis reinvention, yaitu pelayanan yang didasarkan pada "effectiveness, efficiency, adaptability and capacity to innovate."

Dengan demikian konsep ini bertolak belakang dengan pelayanan publik yang cenderung dipengaruhi oleh kapitalisme abad ke-18 dan ke-19 di Eropa Barat yang hanya diukur oleh kapasitasnya untuk menyebarkan jenis rasionalitas instrumental seperti tercermin dalam mesin atau birokrasi absolut ala Max Weber. Masyarakat industri telah melemahkan bentuk kekuasaan tradisional dan karismatik, dan telah melahirkan legal rational sebagai bentuk kekuasaan paling efisien. ${ }^{3}$

Kasus-kasus tindak pidana korupsi yang melibatkan para penyelenggara pemerintahan yang ada saat ini, seperti pelayanan sertifikat tanah yang cenderung sangat lambat dan berbelit, dapat menjadi satu tolok ukur bahwa kinerja pejabat pemerintah terhadap kepuasan konsumennya masih sangat rendah. Begitu pula dengan pelayanan administrasi kependudukan oleh dinas kependudukan di masing-masing daerah yang cenderung lambat. Bila hal semacam ini tidak segera ditindak lanjuti, maka dapat membahayakan hak atas kepastian hukum bagi masyarakat dan banyak terjadi tindakan pelanggaran hukum dalam pelayanan publik.

\footnotetext{
Wayne Parsons, Public Policy; Pengantar Teori dan Praktek Analisis Kebijakan (Kencana Prenada Media Group 2011) 24-25, 274 dan 275. Lihat juga Edi As'Adi, 'Rekonstruksi Regulasi Energi Nasional dalam Melindungi Hak Rakyat atas Energi Berbasis Hukum Progresif: Studi Regulasi Harga Keekonomian Bahan Bakar Minyak Bersubsidi' (disertasi Program Doktor Ilmu Hukum Universitas Diponegoro 2015) 72 dan 83.

2 David Osborn dan Peter Plastrik, Banishing Bureaucracy: The Five Strategies for Reinventing Government (Addison Wesley Publishing Company 1996) 13-14. Ibid.
} 
Lembaga Ombusdman sebagai institusi yang berdiri berdasarkan Undang-Undang Nomor 37 Tahun 2008 tentang Ombudsman Republik Indonesia (UU No. 37 Tahun 2008) seharusnya diharapkan dapat menjadi elemen penegakan hukum pelayanan publik yang baik, transparan, efisien nampaknya cenderung pasif dan tidak proaktif membela hak rakyat atas pelayanan publik yang baik dan memuaskan dan bahkan cenderung koruptif.

Fakta menyebutkan pada 2015, Ombusdman menerima 6.859 laporan, dan pada April 2016 mencapai 2000 laporan, data ini cenderung meningkat. Ombusdman mencatat ada 10 institusi penyelenggara pelayanan publik yang tidak mencerminkan prinsip reinvention yaitu dinas-dinas pelayanan publik pada pemerintah daerah, kepolisian, BUMN/ BUMD, Badan Pertanahan Nasional, lembaga peradilan, lembaga pendidikan negeri, perbankan, perguruan tinggi, rumah sakit pemerintah. ${ }^{4}$

Bertolak dari uraian di atas dapat ditelaah beberapa persoalan yang selama ini menjadi perdebatan di kalangan akademisi terhadap problematika penegakan hukum pelayanan publik oleh Ombudsman dalam mewujudkan pemerintahan yang baik, bersih dan berwibawa sebagai berikut. Pertama, seberapa besar eksistensi Ombudsman berdasarkan UU
No. 37 Tahun 2008 saat ini. Kedua, bagaimana semestinya penegakan hukum pelayanan publik yang dapat memuaskan masyarakat.

\section{PEMBAHASAN}

\section{Eksistensi Ombudsman Berdasarkan UU No. 37 Tahun 2008 Saat Ini}

Seperti diketahui bahwa kencenderungan perilaku koruptif yang dilakukan oleh oknum penyelenggara pelayanan publik selama ini merupakan kesalahan persepsi terhadap penafsiran makna penegak hukum oleh penyelenggara negara. Menurut Bagir Manan, hal itu timbul karena proses penegakan hukum dalam prosedur administrasi tidak berjalan sebagaimana mestinya, berawal dari kesalahan persepsi tentang apa yang dimaksud penegakan hukum dan siapa saja yang menjadi penegak hukum: "Penegakan hukum semata-mata diartikan sebagai apa yang disebut pro-justicia yang dikerjakan kepolisian, kejaksaan dan hakim." 5

Sejalan pemikiran Bagir Manan di atas, penulis berpendapat bahwa pada dasarnya dari penafsiran kalimat penegakan hukum dapat dibagi menjadi dua cara yaitu pro-justicia oleh alat negara seperti di sebut di atas dan penegakan hukum di luar proses yudisial seperti penegakan hukum dalam lingkungan Bea Cukai, laporan-statistik.html?download=252:laporan-statistik-tahun-2015> diakses 30 Maret 2016.

$5 \quad$ Hera Khaerani, Prof. Bagir Manan, "Penegakan Hukum dalam Prosedur Administrasi Tidak Berjalan Sebagaimana Mestinya"'<http://news.unpad.ac.id/?p=46563> diakses 25 Maret 2016. 
keimigrasian, administrasi perpajakan, lembaga pemasyarakatan, lembaga dan lain sebagainya, termasuk oleh lembaga ombudsman.

Dalam pandangan yang sama tentang makna penegakan hukum, C.F.G. Sunaryati Hartono menegaskan bahwa pengertian mengenai penegakan hukum kini perlu dibenahi. Penegak hukum itu bukan hanya yang mengadili sengketa hukum, tetapi juga birokrat. Sistem hukum juga bukan hanya sekumpulan norma-norma melainkan sistem pengelolaan berbangsa dan bernegara yang termasuk di dalamnya adalah norma-norma.

Dewasa ini, kegaduhan hukum pelayanan publik cenderung semakin masif dan cenderung koruptif. Seperti pendapat Adnan Buyung Nasution bahwa wajah hukum kita sudah seperti benang kusut. Ombudsman yang diharapkan menjadi pilar penjaga kebersihan lembaga penyelenggara pemerintahan mulai dari tingkat desa sampai dengan pemerintah pusatpun hanya sebatas rekomendasi, bukan sanksi penegakan hukum. Lebih lanjut Bagir Manan berpendapat bahwa revitalisasi penegakan hukum diperlukan untuk mewujudkan penegakan hukum yang komprehensif, mendasar, efektif, efisien, dan produktif, sebagai jalan menuju penegakan hukum yang berkualitas, tepat, dan benar. Ia juga menekankan bahwa revitalisasi harus disertai dengan berbagai perbaikan, seperti mutu sumber daya manusia, perundang-undangan, sistem pengelolaan, fasilitas dan kesejahteraan, dan sebagainya.

Dengan demikian dapat disimpulkan bahwa pada dasarnya penegakan hukum secara pro-justicia oleh polisi, jaksa dan hakim ataupun secara non pro-justicia oleh lembaga Obmbusdman keberhasilannya diukur berdasarkan cita-cita bernegara untuk mewujudkan pelayanan publik berbasis partisipasi masyarakat di dalam negara hukum yang efektif berkeadilan sosial dan pelayanan publik yang mampu menjadi sarana rekayasa sosial (law as a tool social engineering) dalam mencapai tingkat kesejahteraan dan sebesarbesarnya kemakmuran rakyat.

Mengenai partisipasi masyarakat dalam penegakan hukum Mahfud MD pernah menyampaikan bahwa:

1. Produk (atau sarana penegakan) hukum responsif/populistik adalah produk hukum yang mencerminkan rasa keadilan dan memenuhi harapan masyarakat, dalam proses pembuatannya (law-making process) membuka kesempatan luas dan partisipasi penuh kelompokkelompok sosial (interest group) atau individu dalam masyarakat, outcome atau hasilnya bersifat responsif terhadap tuntutan-tuntutan kelompok sosial atau individu dalam masyarakat.

2. Penegakan hukum melalui produk hukum yang berkarakter konservatif/ortodoks/elitis adalah produk hukum yang isinya lebih mencerminkan visi sosial elit politik/ birokrasi ala absolutisme Weberian, 
lebih mencerminkan keinginan pemerintah birokratis, bersifat positivis-instrumentalis, yakni menjadi alat pelaksana ideologi dan program negara. Hukum ortodok cenderung lebih tertutup terhadap tuntutan kelompok ataupun individu-individu di dalam masyarakat di mana dalam proses pembuatannya partisipasi masyarakat relatif kecil. ${ }^{6}$

Sejalan dengan Mahfud MD di atas, mengenai karakteristik penegakan hukum pelayanan publik yang kedua itu, Yos Johan Utama menyampaikan bahwa karakteristik semacam itu merupakan bentuk State administration yang oleh Leonard D. White dimaknai bahwa "Public Administration consist ... all those operations having for the purpose the fulfillment and enforcement of public policy." Dengan demikian pelayanan publik semestinya juga meliputi penegakan hukumnya melalui lembaga Ombusdman sebagai lembaga yang berwenang menindak penyelenggara pemerintahan yang terdiri atas semua kegiatan negara dengan maksud untuk menunaikan dan melaksanakan kebijakan negara.

Di sisi lain Dimock dan Koenig meyampaikan bahwa penyelenggara pelayanan publik juga merupakan bagian dari aparatur negara dalam melaksanakan kekuatan politiknya diimplementasikan ke dalam penyelenggaraan pemerintahan di semua lini. Dengan demikian yang menjadi sasaran penegakan hukum oleh Ombusdman menurut Prajudi Atmosudirdjo adalah seluruh jajaran aparatur negara, aparatur pemerintahan, atau sebagai institusi politik (kenegaraan), dalam menjalankan fungsinya sebagai administratur negara (bestuur) atau sebagai "fungsi" atau sebagai aktivitas melayani pemerintah dan masyarakat yakni sebagai kegiatan "pemerintah operasional" atau dengan kata lain administrasi negara sebagai proses teknis penyelenggaraan undangundang. Artinya, bila demikian, penyelenggara administrasi negara dalam ketentuan pelayanan publik bertangung jawab sepenuhnya terhadap tercapainya tujuan Undang-Undang Nomor 25 Tahun 2009 tentang Pelayanan Publik (UU No. 25 Tahun 2009) berdasarkan azas-azas yang telah digariskan. Dengan begitu kegiatan pelayanan publik yang menyimpangi ketentuan yang berlaku semestinya dapat langsung ditindak oleh Ombusdman.

Penegakan hukum oleh Ombusdman di atas oleh Prajudi Atmosudirdjo merupakan pokok-pokok tugas dan fungsinya yang seharusnya dapat diimplementaskan, yaitu untuk melaksanakan dan menyelenggarakan kehendak-kehendak (strategi, policy) serta keputusan-keputusan pemerintah secara nyata (implementasi); dan menyelenggarakan undang-undang (menurut pasal-pasalnya) sesuai dengan

\footnotetext{
$6 \quad$ Moh. Mahfud MD, Politik Hukum di Indonesia (RajaGrafindo Persada 2009) 30-31.
} 
peraturan-peraturan pelaksanaan yang ditetapkan.

Secara yuridis, kewenangan penegakan hukum oleh Ombusdman cenderung sangat tumpul seperti diformulasikan ke dalam Pasal 1 angka 1 UU No. 37 Tahun 2008 yaitu: "lembaga negara yang mempunyai kewenangan mengawasi penyelenggara pelayanan publik, baik yang diselenggarakan oleh Badan Usaha Milik Negara, Badan Usaha Milik Daerah, dan Badan Hukum Milik Negara serta badan swasta atau perseorangan yang diberi tugas menyelenggarakan pelayanan publik tertentu yang sebagian atau seluruh dananya bersumber dari Anggaran Pendapatan dan Belanja Negara dan/ atau Anggaran Pendapatan dan Belanja Daerah." Lebih lanjut dalam Pasal 1 angka 7 UU No. 37 Tahun 2008 disebutkan bahwa kewenangan Ombudsman hanya sebatas merekomendasikan kepada pihak yang lebih berwenang melakukan penegakan hukum terhadap penyelenggara pelayanan publik yang telah melakukan maladministrasi. Hal itu nampak tersirat dari definisi yang diberikan oleh Pasal 1 angka 7 UU No. 37 Tahun 2008 tentang rekomendasi, yaitu: "kesimpulan, pendapat dan saran yang disusun berdasarkan hasil investigasi Ombudsman kepada atasan Terlapor untuk dilaksanakan dan/atau ditindaklanjuti dalam rangka peningkatan mutu penyelenggaraan administrasi pemerintahan yang baik."

Dengan demikian dapat disimpulkan bahwa bilamana kedudukan dan eksistensi lembaga Ombusdman hanya sekedar sebagai "pengawas" penyelenggara pelayanan publik sudah dapat dipastikan hasilnya yaitu tujuan menciptakan pemerintahan yang baik dan bersih hanya menjadi sebuah retorika semata, dan cenderung melenceng dari pertimbangan umum yang melatarbelakangi lahirnya UU No. 37 Tahun 2008 tersebut. Oleh karena itu sudah saatnya kedudukan dan peran Ombusdman semakin diperluas sampai pada tingkat penindakan atau penegakan hukum terhadap penyimpangan pelayanan publik yang baik untuk melindungi, membahagiakan dan mensejahterakan rakyat berlandaskan kepada nilai filosofis keadilan sosial.

Meski demikian tidak dipungkiri bahwa tujuan untuk menjadikan lembaga Ombusdman selain sebagai pengawas juga penindak atau (law implementing institutions) cenderung terkendala oleh beberapa hal seperti disampaikan oleh Yos Johan Utama, yaitu:

1. Belum adanya peraturan payung sistem penegakan hukum administrasi;

2. Munculnya pola administrasi negara yang tidak standar;

3. Munculnya lembaga-lembaga baru non-departemen (bersifat ad hoc) yang mempunyai tugas-tugas reguler dari lembaga-lembaga yang sudah ada, sehingga mengurangi luas kewenangannya, dan cenderung menimbulkan saling tindih kewenangan tersebut;

4. Masih adanya urusan pemerintahan yang seharusnya diserahkan kepada 
daerah, akan tetapi justru masih ditangani oleh pemerintah pusat;

5. Akibat adanya pemaknaan yang keliru terhadap otonomi daerah, arogansi daerah dalam bentuk munculnya berbagai peraturan daerah yang bertentangan dengan ketentuan pusat, atau menghambat kebijakan-kebijakan utama pemerintah pusat;

6. Pembangkangan daerah terhadap beberapa kebijakan dan peraturan di tingkat menengah, dengan alsasan telah menginduk dengan ketentuan yang lebih tinggi;

7. Terjadinya tumpang tindih kebijakan administrasi untuk penanganan pengaturan suatu masalah;

8. Malfungsi peradilan administrasi maupun akses-akses penyelesaian sengketa di bidang administrasi negara, sehingga tidak mampu melindungi warga negara;

9. Sistem hukum administrasi keuangan yang tidak/kurang mendukung progresivitas pencapaian pembangunan;

10. Penalisasi hukum administrasi;

11. Lebih menitikberatkan kepada procedure daripada outcome;

12. Pengembangan hukum administrasi yang lebih mengedepankan sisi suspect di banding trust;

13. Materi muatan hukum administrasi yang lebih banyak bersifat pengaturan, dan bukan yang memotivasi peran masyarakat.
Berdasarkan beberapa kendala penegakan hukum administrasi, khususnya kepada penyelenggara pelayanan publik di atas, dapat disimpulkan bahwa pada hakikatnya bilamana perspektif UU No. 37 Tahun 2008 hanya sebatas lembaga pengawas bukan lembaga penegakan hukum, tentu relatif sulit mewujudkan penegakan hukum pelayanan publik yang berkeadilan, berkemanfaatan dan berkepastian hukum seperti ajaran Gustav Radburch. Masing-masing unsur di dalam sistem hukum (atau subsistem struktur hukum, sub-sistem substansi hukum dan sub-sistem kultur hukum) tersebut dalam tataran paling umum berfungsi untuk melindungi dan mendistribusikan alokasi nilai-nilai yang benar menurut masyarakat. ${ }^{7}$

\section{Ombusdman sebagai Penegak Hukum Pelayanan Publik Yang Dapat Memuaskan Masyarakat: Perspektif Asas Legalitas di Masa Depan}

Sebagaimana telah diuraikan di atas, penegakan hukum administrasi, khususnya terhadap penyelenggara pelayanan publik, melalui lembaga projusticia menurut Bagir Manan dan Sunaryati Hartono adalah perspektif yang salah terhadap penafsiran penegakan hukum itu sendiri. Dengan pemikiran demikian maka penegakan hukum oleh Ombusdman sudah saatnya mulai dikedepankan dengan memperluas kewenangan penegakan

Friedman dalam Legal System menjelaskan bahwa di dalam konsep keadilan terdapat gagasan mengenai bagaimana mempertemukan orang dan hal apa yang pantas mereka dapatkan, ditinjau secara etis, tidak lebih dan tidak kurang. Lawrance M. Friedman, Sistem Hukum: Perspektif Ilmu Sosial (Nusamedia 2009) 19. 
hukum terhadap administrator negara untuk mewujudkan tujuan negara yang telah digariskan oleh para pendiri negara Indonesia.

Tujuan negara sebagai arahan dan tolok ukur politik hukum nasional menekankan pentingnya perlindungan hukum bagi rakyat Indonesia dalam menjalankan aktivitas kehidupannya. Akan tetapi dewasa ini lahirnya undangundang sebagai alat pengatur kehidupan sosial cenderung belum dapat mencapai apa yang diamanatkan oleh konstitusi UUD Negara RI 1945 tersebut, untuk itu diperlukan upaya pembaharuan hukum terintegral dan komprehensif yang disesuaikan dengan dinamika kehidupan manusia sebagai objek pemberlakuan hukum. Sebab hukum merupakan resultante dari perubahan masyarakat. ${ }^{8}$

Dengan demikian pada dasarnya penegakan hukum secara pro-justicia oleh polisi, jaksa dan hakim selama ini hanyalah kelanjutan dari rekomendasi Ombusdman dan bagian kecil sarana kontrol sosial masyarakat yang dapat menjadi obat mujarab bagi keseluruhan persoalan kejahatan maladministrasi yang berpotensi muncul di tengah penyelenggaraan pelayanan publik. ${ }^{9}$

Reinvention dalam penegakan hukum pelayanan publik oleh Ombusdman akan memuaskan dan melindungi menjadi lebih berkeadilan, berkemanfaatan dan berkepastian hukum bilamana disertai penegakan hukum yang demokratis, dengan tetap mengedepankan asas legalitas, Asas legalitas dimaksudkan untuk melindungi kepentingan hak-hak warga negara dari pendefinisian perbuatan pidana yang dilakukan secara sewenang-wenang. Untuk mencegah pendefinisian yang sewenang-wenang ini, maka pendefinsian harus dilakukan dengan undang-undang pidana. Pendefinisian perbuatan pidana dengan undang-undang mempunyai makna ganda. Pertama, tidak ada suatu penuntutan jika suatu perbuatan tidak dinyatakan sebagai mala prohibita ini berarti crimina extra ordinaria tidak akan dituntut, dan kedua, harus dilakukan penuntutan terhadap mala prohibita, karena warga negara dianggap tahu dan mau menerima resiko dari perbuatan yang dilakukan. Asas legalitas hanya berorientasi kepada hak-hak dan kepentingan pelaku (offender oriented). Pelaku tidak akan dituntut jika perbuatannya bukan merupakan mala prohibita. ${ }^{10}$ Secara aksiologis, asas legalitas hanya memberikan nilai manfaat kepada pelaku maladministrasi pelayanan publik.

Sejarah Asas legalitas tersebut kali pertama diucapkan oleh sarjana hukum Jerman von Feuerbach (1775-1833), Nullum delictum nulla poena sine praevia

8 Sulistyanta, 'Implikasi Tindak Pidana di Luar KUHP dalam Hukum Acara Pidana (Studi Kasus Taraf Sinkronisasi)' (2013) 13 Jurnal Dinamika Hukum 179, 180.

$9 \quad$ Agus Rahardjo, 'Problematika Asas Retroaktif dalam Hukum Pidana Indonesia' (2008) 8 Jurnal Dinamika Hukum 70, 71.

10 Deni SB Yuherawan, 'Kritik Ideologis Terhadap Dasar Kefilsafatan Asas Legalitas dalam Hukum Pidana' (2012) 12 Jurnal Dinamika Hukum 221, 224. 
lege. Yang ternyata asas legalitas sebelumnya telah dituliskan di dalam buku Mostesquieu, L'esprit des Lois (1748) dan buku Rousseau, Die Contract Social (1762). Selanjutnya asas tersebut dirumuskan sebagai wet atau UndangUndang Dasar di era Revolusi Perancis, seperti ternyata pada rumusan Pasal 8 Declaration des droits de L'homme et du citoyen (1789). Kemudian di masa pemerintahan Napoleon (1801) asas tersebut dirumuskan ke dalam Pasal 4 Code Penal Perancis. Sedangkan di Nederlands yang ketika itu sebagai jajahan Napoleon, asas legalitas dirumuskan di dalam Pasal 1 Wetboek v.Strafrecht Nederlands 1881. Akhirnya akibat adanya asas konkordansi antara Nederlands Indie dan Nederlans, maka asas legalitas dimasukkan ke dalam Pasal 1 W.v.S Nederlands Indie 1918. ${ }^{11}$ Asas legalitas atau asas pertanggungjawaban pidana adalah: tidak dipidana maladministrasi jika tidak ada kesalahan (Geen Straf Zonder schuld; Actus non facit reum nisi mens sit rea), sebaliknya, pertanggungjawaban tanpa adanya kesalahan bagi yang melanggar disebut leer van het materiele feit atau fait materielle. Sesuai dengan tujuan yang tidak hanya sebagai alat ketertiban. Artinya pembuatan, penerapan dan penegakan hukum pelayanan publik memiliki tujuan untuk pembaharuan masyarakat (social engineering). ${ }^{12}$
Secara sosiologis hukum menjadi sarana untuk tercapainya keadilan dan ketertiban masyarakat serta harus mencerminkan aspek filosofis, yuridis, sosiologis dan historis sehingga kehidupan bangsa dan negara harus berkesinambungan. Meskipun tidak dapat dipungkiri bahwa membicarakan hukum di tingkat implementasinya, maka kesadaran utama yang harus dimunculkan adalah, ketika hukum sudah diimplementasikan di masyarakat, maka hukum hanya merupakan salah satu sub-sistem di dalam masyarakat. Masih ada subsistem lain yang bekerja di masyarakat, seperti sub-sistem politik, sub-sistem ekonomi, sub-sistem budaya, subsistem agama dan sejenisnya. Dengan demikian berlakunya aturan hukum itu pun akan terpengaruh oleh sub-sistem yang lain. ${ }^{13}$

Keadilan dalam konteks teori politik koheren yang biasa digunakan untuk menjastifikasi hukum komunitas secara keseluruhan, didasarkan pada ide kesejahteraan kolektif, atau konsepsi hak politik dan sosial masyarakat dalam hal ini kususnya hak rakyat untuk mendapatkan pelayanan publik yang baik dan profesional, atau teori kewajiban moral komunal. ${ }^{14}$ Teori politik hukum senantiasa meletakkan idea-idea keadilan untuk mengatur tujuan kolektif, hak individual dan kewajiban individual dengan suatu cara membuat

\footnotetext{
11 Ibid.

12 So Woong Kim, 'Kebijakan Hukum Pidana dalam Upaya Penegakan Hukum Lingkungan Hidup' (2013) 13 Jurnal Dinamika Hukum 415, 418.

13 F.X. Adji Samekto, 'Relasi Hukum Dengan Kekuasaan: Melihat Hukum dalam Perspektif Realitas' (2013) 13 Jurnal Dinamika Hukum 89, 90.

$14 \quad$ R.M. Dworkin, Filsafat Hukum: Sebuah Pengantar (Merkid Press 2013) 21.
} 
seperangkat aturan fundamental dan aturan lainnya. ${ }^{15}$

Dengan demikian dalam pembaharuan hukum pelayanan publik (termasuk pembaharuan terhadap kewenangan Ombusdman sebagai struktur dalam system hukum), harus ditempuh melalui pendekatan yang berorientasi pada kebijakan (policyoriented approach) karena memang pada hakikatnya ia hanya merupakan bagian dari suatu langkah kebijakan atau policy (yaitu bagian dari politik hukum/ penegakan hukum dan politik sosial), dan sekaligus pendekatan yang berorientasi pada nilai (value-oriented approach) karena dalam setiap kebijakan (policy) terkandung pula pertimbangan nilai.

Politik hukum pelayanan publik dengan mengedepankan reformulasi kewenangan Ombusdman dalam penegakan hukum administrasi nasional secara komprehensif dan integral meliputi subsistem substansi hukum, struktur hukum, dan budaya hukum di bidang pelayanan publik di masa depan sudah semestinya dilakukan dan disenergikan dengan semangat Pancasila yang corenya adalah nilai kedilan sosial dan prinsip-prinsip hak asasi manusia yang tercakup di dalam Pasal 28 UUDNRI 1945. Untuk pembaharuan hukum pelayanan publik melalui perluasan kewenangan Ombusdman sebagai penegak hukum maka seyogyanya perlu dilakukan pengkajian dan penggalian nilai-nilai nasional yang bersumber pada Pancasila dan nilai-nilai yang ada di masyarakat (nilai-nilai religius maupun nilai-nilai budaya/adat).

Pelanggaran hukum terjadi karena lemahnya diseminasi dan penyuluhan hukum menjadi bagian dari tanggung jawab penyelenggara negara. Pelaksanaan diseminasi dan penyuluhan hukum adalah unsur yang tidak dapat dipisahkan dari penerapan asas fiksi hukum yang menyatakan bahwa "setiap orang dianggap tahu hukum". Kaitannya dengan tindakan penegakan hukum dalam semua faktor hukum harus selalu dibarengi dengan upaya preventif berbentuk sosialisasi produk-produk hukum yang sungguh perlu ditingkatkan sebab dengan berhasilnya upaya preventif dapat mengurangi tingkat pelanggaran hukum, tentu akan lebih maslahat dan tidak menimbulkan kerugian yang lebih besar dibandingkan dengan upaya represif setelah terjadinya pelanggaran. Dengan demikian, penegak hukum dapat melaksanakan fungsinya sebagai pengayom, sesuai dengan tujuan hukum, yaitu keadilan dan ketertiban, karena fungsi hukum itu sendiri selain sebagai pencipta keteraturan (order), juga harus dapat memberikan perlindungan bagi rakyat sebagai konsumen pengguna jasa pelayanan publik untuk memperoleh keadilan bukan untuk menyengsarakan.

Dinamika kehidupan masyarakat sudah semestinya dilengkapi dengan 
pembaharuan hukum nasional yang baik, hukum yang baik adalah hukum yang selalu mengikuti perkembangan masyarakat. Perubahan dan perkembangan masyarakat selalu bergerak dinamis. ${ }^{16}$ Dinamika bekerjanya hukum menurut Chamblis dan Seidman dipengaruhi oleh variabelvariabel di dalam domain pemerintah, pemegang peran dan institusi penegak hukum serta variable timbal balik serta tuntutan masyarakat luar, di era masyarakat ekonomi ASEAN dan globalisasi ekonomi yang memerlukan kecepatan dan ketepatan pelayanan publik.

Di masa depan melalui konsep reinventing dengan memberikan perluasan kewenangan penagakan hukum kepada Ombusdman diharapkan usaha mewujudkan pembaharuan sistem hukum pelayanan publik secara menyeluruh dan terintegrasi meliputi substansi hukum atau UU No. 25 Tahun 2009, struktur hukum atau organ penegak hukum Ombusdman melalui pembaharuan UU No. 37 Tahun 2008 dan budaya perilaku masyarakat dalam usahanya menggunakan jasa pelayanan publik.

Dengan demikian Ombusdman menjadi titik sentral dalam penegakan hukum pelayanan publik yang baik guna mewujudkan Good Government and Clean Government. Artinya, benang merah hubungan tujuan negara untuk memajukan kesejahteraan umum, salah satunya dapat dilakukan melalui pelayanan publik yang baik, transparan, efektif, efisien, berdedikasi, inovatif berorientasi kepada kepuasan masyarakat sebagai bentuk perlindungan hak rakyat atas kebutuhan administrasinya yang meliputi administrasi kependudukan, administrasi pertanahan, administrasi kendaraan, administrasi kesehatan, administrasi pendidikan dan lain sebagainya.

\section{PENUTUP}

Berdasarkan uraian pembahasan di atas dapat ditarik kesimpulan sebagai berikut. Eksistensi Ombusdman dalam penegakan hukum pelayanan publik sampai saat ini cenderung belum dapat menyentuh kepada oknum penyelengara pelayanan publik yang melakukan maladministrasi, hal ini dikarenakan kewenangan yang diberikan oleh undang-undang hanya terbatas kepada fungsi pengawasan, dengan demikian proses penegakan hukum dalam prosedur administrasi tidak berjalan sebagaimana mestinya, hal ini berawal dari kesalahan persepsi tentang apa yang dimaksud penegakan hukum.

Di masa depan diperlukan reformulasi kewenangan Ombusdman sebagai upaya pembaharuan hukum pelayanan publik nasional, sebab Ombusdman sebagai titik sentral dalam penegakan hukum pelayanan publik yang baik guna mewujudkan Good Government and Clean Government,

16 Muhammad Fauzan, Djumadi, dan Riris Ardhanariswari 'Perumusan Ketentuan Pidana dalam Pembentukan Peraturan Daerah (Studi di Kabupaten Purbalingga)' (2008) 8 Jurnal Dinamika Hukum 154, 160. 
artinya benang merah hubungan tujuan negara untuk memajukan kesejahteraan umum salah satunya dapat dilakukan melalui pelayanan publik yang baik, transparan, efektif, efisien, berdedikasi, inovatif berorientasi kepada kepuasan masyarakat sebagai bentuk perlindungan hak rakyat atas kebutuhan administrasinya, meliputi administrasi kependudukan, administrasi, pertanahan, administrasi kendaraan, administrasi kesehatan, administrasi pendidikan dan lain sebagainya.

\section{DAFTAR BACAAN}

\section{Buku}

Dworkin, R.M., Filsafat Hukum: Sebuah Pengantar (Merkid Press 2013).

Friedman, Lawrance M., Sistem Hukum: Perspektif Ilmu Sosial (Nusamedia 2009).

Mahfud MD, Moh., Politik Hukum di Indonesia (RajaGrafindo Persada 2009).

Osborn, David, dan Peter Plastrik, Banishing Bureaucracy: The Five Strategies for Reinventing Government (Addison Wesley Publishing Company 1996).

Parsons, Wayne, Public Policy; Pengantar Teori dan Praktek Analisis Kebijakan (Kencana Prenada Media Group 2011).

\section{Jurnal}

Fauzan, Muhammad, Djumadi, dan Riris Ardhanariswari 'Perumusan Ketentuan Pidana dalam Pembentukan Peraturan Daerah (Studi di Kabupaten Purbalingga)' (2008) 8 Jurnal Dinamika Hukum 154.

Kim, So Woong, 'Kebijakan Hukum Pidana dalam Upaya Penegakan Hukum Lingkungan Hidup' (2013) 13 Jurnal Dinamika Hukum 415.

Rahardjo, Agus, 'Problematika Asas Retroaktif dalam Hukum Pidana Indonesia' (2008) 8 Jurnal Dinamika Hukum 70.

Samekto, F.X. Adji, 'Relasi Hukum Dengan Kekuasaan: Melihat Hukum dalam Perspektif Realitas' (2013) 13 Jurnal Dinamika Hukum 89.

Sulistyanta, 'Implikasi Tindak Pidana di Luar KUHP dalam Hukum Acara Pidana (Studi Kasus Taraf Sinkronisasi)' (2013) 13 Jurnal Dinamika Hukum 179.

Yuherawan, Deni SB, 'Kritik Ideologis Terhadap Dasar Kefilsafatan Asas Legalitas dalam Hukum Pidana' (2012) 12 Jurnal Dinamika Hukum 221. 


\section{Disertasi}

As'Adi, Edi, 'Rekonstruksi Regulasi Energi Nasional dalam Melindungi Hak Rakyat atas Energi Berbasis Hukum Progresif: Studi Regulasi Harga Keekonomian Bahan Bakar Minyak Bersubsidi' (disertasi Program Doktor Ilmu Hukum Universitas Diponegoro 2015). 